\title{
Direitos Humanos em tempos de barbárie
}

\author{
Alana Regina Sousa de Menezes \\ Educadora Social na Prefeitura Municipal de Três Lagoas, no estado de Mato Grosso do \\ Sul. Mestre em Letras pela Universidade Federal de Mato Grosso do Sul (UFMS). \\ Especialista em Metodologia do Ensino Superior pela Faculdade São Luís de França \\ (Aracaju/SE). Bacharelanda em Direito pela Universidade Federal de Mato Grosso do Sul \\ (UFMS). E-mail: alanareginasm@hotmail.com.
}

\section{Gisele Dayani Milani}

Assistente Social concursada na Prefeitura Municipal de Três Lagoas, Mato Grosso do Sul. Doutoranda em Serviço Social pela Pontifícia Universidade Católica de São Paulo (PUC/SP) e bolsista CAPES. Mestre em Serviço Social pela PUC/SP (2016) e mestre em Economia (2016) especialidade Avaliação e Gestão de Políticas Sociais pela Université Pierre-Mèndes France - UPMF em Grenoble, França. Representante Discente de Pós-Graduação (suplente) na Associação Brasileira de Ensino e Pesquisa em Serviço Social - ABEPSS, biênio 2017-2018 “Quem é de luta, resiste”. E-mail: giselemilani@hotmail.com.

\section{Resumo}

Este artigo apresenta elementos para discutirmos a barbárie causada pela ausência de respeito aos direitos humanos. Amparada por pressupostos jurídicos e pela vertente social do tema, esta pesquisa tem o objetivo de fazer suscitar discussão a respeito do atual contexto paradoxal entre a expectativa de avanços no que tange às garantias fundamentais e a realidade de inúmeras violações a esses direitos, o que resulta em um quadro de insegurança (tanto jurídica, quanto social). Para o alcance desse objetivo foi fundamental o levantamento de dados, a partir de pesquisa bibliográfica, especialmente. Busca-se compreender a temática a partir de autores com estreita afinidade com o tema. Nessa perspectiva, fizeram-se basilares, dentre outras, as contribuições de Barroso (2015); Barroco (2013, 2015, 2016); Piovesan (2000, 2008, 2016); Mazzuoli (2014) e Ramos (2016). O teor das discussões travadas aponta para oscilantes momentos de conquistas e declínios e para um preocupante momento de crueldades explícitas.

\section{Palavras-chave}

Direito constitucional; Direito internacional; Direitos fundamentais; Segurança Pública; Minorias. 


\title{
Human Rights during barbarism times
}

\begin{abstract}
This article presents elements to discuss the barbarism caused by the absence of respect for human rights. Based on legal presuppositions and social aspect of the theme, this research aims to raise the discussion about the current paradoxical context between the expectation of advances regarding fundamental guarantees and the reality of numerous violations of these rights, which results in a framework of insecurity (both legal and social). In order to achieve this objective, it was fundamental to collect data, especially from bibliographical research. It is sought to understand the theme from authors with close affinity with the theme. From this perspective, were basic, among others, the contributions of Barroso (2015); Barroco (2013, 2015, 2016); Piovesan (2000, 2008, 2016); Mazzuoli (2014) and Ramos (2016). The content of the discussions indicate points to oscillating moments of achievements and declines and to a troubling moment of explicit cruelties.
\end{abstract}

\section{Keywords}

Constitutional Law; International Law; Fundamental Rights; Public Safety; Minorities.

\section{Sumário}

Introdução. 1. Direitos Humanos: pretensões globais e brasileiras. 2. Horrores de uma guerra não declarada. 2.1. Violência contra as minorias. 2.2. As chagas do crime de estupro no Brasil. Considerações Finais. Referências.

\section{Introdução}

A barbárie, própria do sistema capitalista e de sua lógica destrutiva, se expressa nos níveis absurdos de violência, de destruição dos direitos (historicamente conquistados), na exploração e precarização do trabalho, na opressão de gênero, classe, orientação sexual, raça e etnia.

Pensando nisso, este artigo foi elaborado em tempos de estardalhaço direitista, de destruição de direitos historicamente e arduamente conquistados, dos novos e dos de sempre modos de violação de direitos humanos ocasionados, sobretudo, por discriminações e fundamentalismos.

A pesquisa (quanto à metodologia, do tipo bibliográfica e documental) foi dividida, para isso, em dois momentos. No primeiro deles, há uma síntese histórica, a título de contextualização, para que sirva de ponto de partida a uma compreensão ampla e circunstancial dos processos que desencadearam na atual concepção de direitos humanos (no Brasil e fora dele).

Depois, utilizando como base os dados do recente Anuário de Segurança Pública (2016), partimos para uma análise que mescla teoria e, literalmente, prática da efetividade dos direitos humanos no Brasil. O objetivo é tentar descobrir onde e por que uma se desalinha da outra, 
buscando compreender a dinâmica social e os interesses estatais envolvidos nesse processo de antagonismo flagrante.

\section{Direitos Humanos: pretensões globais e brasileiras}

O que, atualmente, conhecemos como "direitos humanos" descende de uma morosa construção de bases legais e morais que se deram no percurso histórico das civilizações. Não é à toa que, ao tratar do tema, uma de suas características mais reafirmadas pela doutrina especializada é a historicidade. Uma vez que a história é um movimento contínuo de transformações - entre ruínas e elevações -, a dogmática dos direitos humanos caminha paralelamente a esses ciclos de lutas e opressões.

No âmbito dessas graduais metamorfoses, entretanto, não se pode falar na atual concepção de direitos humanos sem destacar o marco que fez com que se erguesse uma visão mais humanitária da vida, colocando-nos prostrados diante da impensável capacidade humana de autodestruição: o legado da Segunda Guerra Mundial.

Se hoje a doutrina de direitos humanos consegue falar sobre uma gramática desses direitos, muito a ciência jurídica deve aos esforços empreendidos internacionalmente no pós-guerra. Os direitos humanos ocupam o centro das discussões internacionais e são elevados à prioridade na agenda global devido, em grande parte, ao estarrecimento causado pelos pesarosos acontecimentos da guerra.

Evidentemente, não se trata de acreditar que somente depois de um evento tão traumático para a humanidade é que se experimentou pensar e lutar pelos direitos humanos. Como anteriormente dito, trata-se, sobretudo, de sucessivas tentativas de pacificação social (ou, ao menos, de minimização dos conflitos, da miserabilidade, da violência e da truculência que atingem a humanidade). Afinal, "a concepção atual dos direitos humanos é fruto de um longo processo histórico de agregação de valores percebidos e conquistados na luta como fundamentais à condição humana e à convivência coletiva" (KROHLING, 2009, p. 44).

Contudo, a doutrina contemporânea já concordou que a comunidade internacional passa a dar braçadas mais velozes no que tange aos direitos humanos quando do choque do infeliz saldo de horrores advindo do pós-guerra. Tanto o é que, nas palavras do professor Mazzuoli (2014, p. 64), "pode-se dizer que o Direito Internacional dos Direitos Humanos é o 'direito do pós-guerra'”.

Com as repugnantes práticas nazistas e com o Holocausto, ficou nítida a urgência de uma ordem internacional mais atenta e, além de perita e diplomática, enérgica e 
estável.

Nesse contexto, antefere-se a Carta da ONU de 1945 como uma das bases de afirmação dos direitos humanos em âmbito internacional. A prioridade passaria a ser não a feracidade com a qual o Estado pode (porque assim o é permitido) tratar seus cidadãos, mas uma ordem internacional superior que protegesse a dignidade humana, independentemente da nacionalidade (ou de qualquer outra premissa que ocasionasse sua violação) - daí o fato de serem universais e essenciais.

Se a 2a Guerra Mundial significou a ruptura com os direitos humanos, o pósguerra deveria significar sua reconstrução. [...] Prenuncia-se, deste modo, o fim da era em que a forma em que o Estado tratava seus nacionais era concebida como um problema de jurisdição doméstica, decorrência de sua soberania (PIOVESAN, 2000, p. 18).

No entanto, é em 1948, em Paris, que se proclama o instrumento que tem a missão de "estabelecer um padrão mínimo para a proteção dos direitos humanos em âmbito mundial, servindo como paradigma ético e suporte axiológico desses mesmos direitos" (MAZZUOLI, 2014, p. 108). Trata-se da Declaração Universal dos Direitos Humanos que nos seus 30 artigos deixa mais do que evidente seu prisma pantopolista.

Embora a doutrina compreenda a natureza jurídica da Declaração como sendo mera recomendação, ela tem sido fonte inesgotável de inúmeros tratados firmados desde sua concepção. Além disso, no caso do Brasil, por exemplo, a Declaração norteou diversos pontos da atual Constituição nacional.

\footnotetext{
O marco histórico do novo direito constitucional, na Europa continental, foi o constitucionalismo do pós-guerra, especialmente na Alemanha e na Itália. No Brasil, foi a Constituição de 1988 e o processo de redemocratização que ela ajudou a protagonizar. [...] sem embargo de vicissitudes de maior ou menor gravidade no seu texto e da compulsão com que tem sido emendada ao longo dos anos, a Constituição promoveu uma transição democrática bem sucedida e assegurou ao país estabilidade institucional, mesmo em momentos de crise aguda. Sob a Constituição de 1988, o direito constitucional passou da desimportância ao apogeu em menos de uma geração. O surgimento de um sentimento constitucional no país é algo que merece ser celebrado. Superamos a crônica indiferença que, historicamente, se manteve em relação à Constituição. E, para os que sabem, é a indiferença, não o ódio, o contrário do amor (BARROSO, 2015, p. 519).
}

O que se esperava, portanto, era que a Constituição de 1988 contribuísse para firmar uma declaração de direitos e garantias individuais (sobretudo, frente ao poder estatal). O que temos na atual Carta Magna brasileira são normas que, além de organizar os Poderes, determinam a forma de Estado e - o mais importante - declaram direitos. 
Temos, principalmente no nosso artigo 5으, um extenso rol de direitos proclamados fundamentais. A realidade brasileira começa a passar, portanto, por um período que pede (com mais nitidez) que esses direitos passem a ser efetivados e concretizados. Seria, ao menos em tese, o início de uma visão (influenciada pelos movimentos internacionais) mais voltada à dignidade da pessoa humana, ao cuidado com a cidadania e à ruptura de violação de direitos considerados basilares para a construção de uma sociedade justa.

Evidentemente, a realidade dos países difere em diversos aspectos. No entanto, é possível notar uma visionária missão que caminha no sentido de conectar interesses gerais, pautados numa linha comum: o freio aos excessos do Estado frente ao ser humano. Há, nesse movimento, algo de elementar, que é a preservação da dignidade da pessoa humana, como supraprincípio.

Com os ecos da Declaração Universal dos Direitos Humanos na Constituição brasileira de 1988, estaria firmado um compromisso (sobretudo) com o ser humano enquanto sujeito de direitos. O Brasil passaria a estar inserido no claro movimento global do chamado neoconstitucionalismo.

Nesse sentido:

O constitucionalismo contemporâneo, que deu passos largos pela noção
burguesa da propriedade privada, avançou sobre outras temáticas mais
sociais: liberdade de imprensa, liberdade de expressão, respeito às minorias,
reconhecimento de diversidades culturais e étnicas e consciência real das
questões que envolvem a igualdade. Aí está a importância da Constituição
brasileira de 1988, e eis por que é conhecida como a 'Constituição Cidadã'
(CASTILHO, 2010, p. 109).

Contudo, se parece simples colocar em linhas gerais uma síntese da força desejada aos direitos humanos em âmbito nacional e internacional, a efetividade desses direitos teria que ser pensada como um desafio próximo e prudente. No mesmo passo no qual se deu o fortalecimento dos direitos humanos no plano internacional (em meados do século XX, resultante da era "pós-Hitler"), no Brasil, a Constituição democrática vem selar o fim de um regime ditatorial - ela marcaria a retomada de direitos retirados pela ditadura civilmilitar. Efetivar tão sonhados direitos não seria tarefa de tranquila execução. Podemos dizer que há, pelo menos, duas grandes pautas nesse movimento contemporâneo.

[...] 1a) a revisão da noção tradicional de soberania absoluta do Estado, que passa a sofrer um processo de relativização, na medida em que são admitidas intervenções no plano nacional, em prol da proteção dos direitos humanos; isto é, permitem-se formas de monitoramento e responsabilização internacional, quando os direitos humanos forem violados; 2a) a cristalização da ideia de que o indivíduo deve ter direitos protegidos na esfera 
internacional, na condição de sujeito de Direito (PIOVESAN, 2016, p. 59).

Como bem ponderou a professora Flávia Piovesan, trata-se de um sistema organizado em partes de um todo unificado em sentido único: a violência contra o ser humano passa a ser um problema não apenas do Estado onde o ato aconteceu. Negar direitos que firam de morte a dignidade da pessoa humana (alicerce dos direitos humanos) não tem mais a ver com a decisão soberana de um Estado, afinal: “Um Estado que sistematicamente viola a Declaração não é merecedor de aprovação por parte da comunidade mundial" (PIOVESAN, 2016, p. 64).

$\mathrm{Na}$ tentativa de acompanhar as mudanças dos raciocínios político e jurídico mundiais, o texto constitucional brasileiro, portanto, veio a vislumbrar avanços no âmbito dos direitos humanos. Com a redemocratização, além da celebrada Constituição de 1988, o Brasil passa a ratificar importantes tratados que visam diretamente à proteção dos direitos humanos (como, por exemplo, a Convenção Internacional para Prevenir e Punir a Tortura; a Convenção contra a Tortura e outros Tratamentos Cruéis, Desumanos ou Degradantes; a Convenção Americana de Direitos Humanos; e a Convenção Interamericana para Prevenir, Punir e Erradicar a Violência contra a Mulher).

A esse respeito:

Além das inovações constitucionais, como importante fator para a ratificação desses tratados internacionais, acrescente-se a necessidade do Estado brasileiro reorganizar sua agenda internacional, de modo mais condizente com as transformações internas decorrentes do processo de democratização. [...] a subscrição do Brasil aos tratados internacionais de direitos humanos simboliza ainda o aceite do Brasil para com a ideia contemporânea de globalização dos direitos humanos, bem como para com a ideia da legitimidade das preocupações da comunidade internacional, no tocante à matéria. [...] Logo, faz-se clara a relação entre o processo de democratização no Brasil e o processo de incorporação de relevantes instrumentos internacionais de proteção dos direitos humanos, tendo em vista que, se o processo de democratização permitiu a ratificação de relevantes tratados de direitos humanos, por sua vez essa ratificação permitiu o fortalecimento do processo democrático, por meio da ampliação e do reforço do universo de direitos por ele assegurado (PIOVESAN, 2008, p. 25).

Instrumentos criados e protocolados, restava a efetivação do amplo rol de direitos oferecidos - em tese - à cidadã e ao cidadão. Com os compromissos firmados, iniciava-se a esperança de uma nova era, regida pela redemocratização do país, centrada em um forte ideal de humanidade e de ampliação de direitos e garantias.

Todavia, toda a sistemática criada enfrentaria, dentre outros, um grave problema: o da sensibilização da sociedade frente aos direitos humanos. Com toda a complexidade 
que lhes é inata, especialmente no Brasil, ainda se fazem árduos os caminhos para que se estampe uma verdadeira nação que respeita e acredita em um projeto "democratizante e humanista" (PIOVESAN, 2008, p. 33).

Para nos darmos conta do quão penoso é esse itinerário, basta conscientizarmonos das inúmeras crises humanitárias (nacionais e internacionais) que se deflagram na contemporaneidade. As tristes realidades do feminicídio, da homofobia, do racismo, da miserabilidade, da violência urbana, dos genocídios indígenas são demonstrações da dificuldade de colocação em prática, no caso do Brasil, do texto constitucional e dos tratados incorporados ao ordenamento.

Se pensarmos nos dados divulgados pelo 10 을 Anuário de Segurança Pública, publicado pelo Fórum Brasileiro de Segurança Pública, no ano de 2016, podemos detectar inúmeras demandas que tocam com precisão em diversas feridas, ainda abertas, da falta de compreensão e aplicabilidade dos direitos humanos no Brasil. Os números revelam a barbárie que, ainda, se instaura no país, mesmo que estejamos sob a égide de uma “Constituição cidadã”, fundada na dignidade da pessoa humana.

Dentre os cálculos espantosos apresentados pelo Anuário, estão as 279.592 pessoas assassinadas no Brasil contra as 256.124 pessoas mortas na Guerra da Síria, em um período que compreende os anos de 2011 e 2015.

Com o objetivo de detalhar e aprofundar o que está contido no Anuário, traçando uma reflexão panorâmica da atual realidade dos direitos humanos no Brasil, em termos de legislação, aplicabilidade e realidade fática, este artigo parte para uma leitura voltada para as chagas sociais e humanas, no quadro brasileiro, que se apresentam explícitas na contemporaneidade, na tentativa de contribuir para desenvolver um pensamento crítico que consiga diagnosticar os porquês da banalização e do descrédito dos direitos humanos no país.

\section{Horrores de uma guerra não declarada}

Via de "regra", os direitos humanos devem ser respeitados. No entanto, mesmo sem guerra civil declarada, os dados sobre mortes em massa ultrapassam, muitas vezes, o somatório de mortes em conflitos armados. Exemplo disso são as 192.804 vítimas brasileiras, contra um número próximo das 169.574 mortes provocadas nos doze maiores conflitos mundiais entre 2004 e 2007 (BRITO; VILLAR; BLANK, 2013, pp. 216-217; BARROCO, 2015, p. 628). 
Dados do já referido Anuário Brasileiro de Segurança Pública (2016) demonstram que 58.492 pessoas morreram por violências intencionais no ano de 2015 , é como se a cada 09 minutos 01 pessoa fosse morta. Como já adiantamos, na somatória dos últimos cinco anos, o Brasil registrou mais mortes violentas intencionais do que a Guerra na Síria no mesmo período, com 279.592 (de janeiro de 2011 a dezembro de 2015) e 256.125 (de março de 2011 a novembro de 2015) mortes, respectivamente.

\subsection{A violência contra as minorias}

Chamaremos o caso brasileiro de "guerra não declarada". Se analisarmos criticamente, veremos que essa guerra tem um público alvo: atinge mulheres, negros, trabalhadores pobres, pessoas fora do mercado de trabalho, moradores de rua, dentre outros que se enquadrem "fora" do consumo e do pensamento dominante. Apenas para confirmar uma faceta do exposto, dados do Anuário (2016) apontam que 54\% são jovens entre 15 e 24 anos e, dentre estes, $73 \%$ são pretos e pardos.

Cabe aqui uma relação: a história social dos Direitos Humanos é o resultado da pressão popular, da organização dos sujeitos políticos em movimentos e em militâncias. 0 chamado "movimento das minorias", de negros, homossexuais, mulheres, entre outros, registraram na história suas lutas por visibilidade e combate às diversas formas de violência, bem como de exclusão social. Hoje, alcançaram conquistas legais no campo dos direitos civis e políticos devido à oposição e à resistência de parcela da sociedade. No entanto, quando olhamos os dados sobre violência, vemos que ainda não são suficientes ou não implementadas em sua máxima capacidade.

Falar de direitos humanos das minorias remete também a pensar em como se daria sua realização/efetivação face às condições adversas da sociedade capitalista? Haja vista o panorama brasileiro (e também mundial) de insegurança e desproteção social que se generalizam, com rebatimentos, sobretudo, na fragilização da vida e nas formas de violência. Isso porque a realidade do país aponta para o poder econômico como sendo dominante (mais forte que o poder jurídico, inclusive).

Ao outro the é negado o direito de existir com suas "diferenças". Os direitos humanos dos "diferentes" na atual sociedade acabam, por vezes, por se expressarem sob a forma de um processo de desumanização. Como resultado, têm-se "limpezas" étnicas, estupros coletivos, intolerância religiosa, crimes por ódio, entre outros exaustivamente abordados diariamente pela mídia.

Nessa perspectiva: 
A enxurrada de homicídios no Brasil, manchada pela seletividade econômica, étnica e espacial, aloja-se no andamento do processo democrático. Dado o enredamento crescente da violência com os regimes democráticos, cria-se um problema nesses tempos de 'ode à democracia': a manutenção da própria democracia como um persistente estado de exceção sob os influxos das leis férreas da acumulação capitalista. Ocorre um espalhamento da 'exceção' [...] em defesa da própria 'regra', cuja reprodução, contudo, é cada vez mais envolvida pela 'exceção' (e dependente dela) (BRITO; VILLAR; BLANK, 2013, p. 238).

Assistimos a um processo chamado por Barroco (2015, p. 627) de "militarização da vida cotidiana que transforma a exceção em regra, mantendo um Estado de 'exceção' no interior do Estado democrático", como também afirmam Brito, Villar e Blank (2013), um Estado policial dentro do Estado democrático. É importante adicionar ainda a colaboração da mídia nesse processo, como também a legitimação por parte da sociedade (ou sua omissão). Comentadores midiáticos ao exporem um caso de violência definem o que é delito, dão lição de moral e, no pacote, ainda indicam uma solução punitiva.

Com isso, o vigor dos direitos humanos vai se perdendo e sua defesa vai sendo acusada de defesa de bandidos e, por vezes, os profissionais defensores das "minorias" segregados socialmente. A respeito disso, é imperioso lembrar que os direitos humanos não pretendem, sobremaneira, excluir do processo de garantias aquelas pessoas que delinquiram. Ninguém perde a condição de humano, sob nenhuma hipótese; a ideia de dignidade da pessoa humana é civilizatória e significa uma ordem jurídica efetiva e justa, que não atente contra seu próprio Estado de Direito e contra a dogmática internacional. Assim:

Se os direitos humanos são individuais, abrangem todos os indivíduos, inclusive - e especialmente - os infratores. Menciona-se o termo especialmente, porque vários direitos e garantias expressos nos incisos do art. 50 jamais serão aplicados, na prática, a quem nunca delinquir. Por outro lado, a segurança pública é um dever da coletividade, que dispõe de órgãos constituídos justamente para preservá-la, dando suporte a todos. Uma ilustração: a rebelião ocorrida em um presídio, com fuga de condenados, coloca em risco a ordem pública; nem por isso os presos rebeldes ficam automaticamente privados de seus direitos individuais. Nem por isso, para resolver o problema, concede-se ao Estado o direito de matar os que ali estiverem causando a desordem. Cuida-se de assegurar a ordem sem ferir direitos fundamentais. Pode-se dizer que essa situação é difícil e complexa, o que não se nega, mas compatibiliza-se, na integralidade, com o texto constitucional (NUCCl, 2016, p. 86).

Se remetermos nossa análise para o campo das ideologias, veremos que, na verdade, a ideologia "de ódio" aos direitos humanos está presente desde finais do século 
XX: a ideologia pós-moderna. É ela quem nega a história, a racionalidade, a universalidade, a perspectiva de totalidade, isto é, nega princípios e valores que dão sustentação à sociedade moderna e aos direitos humanos. "O grupo que se constitui como intolerante em face dos diferentes é que define os limites do humano tendo por parâmetros a violência, a discriminação, a alienação, a opressão o outro" (BARROCO, 2008, p. 8).

O mais preocupante é a nitidez com a qual se expõe que a defesa legítima dos direitos humanos é barrada quando se colocam como sujeitos de seu protagonismo as camadas marginalizadas da sociedade. Isso se dá de forma mais efetiva quando a busca é por garantias àqueles que são considerados "inimigos" da sociedade. Aqueles que delinquem no Brasil são postos numa situação de "não humano", como se devessem ser expurgados de vez da sociedade, contrariando os ideais de ressocialização, recuperação e transformação do indivíduo.

O delinquente - embora se faça custoso para a sociedade entender - é também uma pessoa, com direitos garantidos internamente e, também, no âmbito internacional. $O$ Estado deveria não apenas garantir os direitos fundamentais da pessoa presa/processada no Brasil; deveria agir para garantir a efetividade do seu próprio ordenamento, da sua ordem interna constitucional e infraconstitucional.

Mais do que os rancores socialmente assumidos (materializados na figura de justiceiros espalhados pelo país), é sintomática a anuência do Estado com uma cultura de violação de direitos das pessoas que cometem crimes, como se fosse possível e plenamente aceitável não destinar nenhum respeito ao pactuado no direito interno e externo.

Segundo os relatórios da ONG Human Rights Watch, a grande maioria dos casos de práticas de tortura (na forma de espancamentos, maus-tratos ou humilhações) ocorre com pessoas mantidas sob a custódia do Estado, em delegacias, cadeias e presídios, ou como método para obtenção de confissões ou como maneira de punição contra atos de indisciplina. $O$ detento costuma ser visto como alguém que não é portador de direitos - e, em geral, é pessoa pobre e marginalizada (CASTILHO, 2010, p. 191).

Nesse sentido, vale lembrar a Convenção Contra a Tortura e Outros Tratamentos ou Penas Cruéis, Desumanos ou Degradantes (1984), promulgada pelo Brasil em 1991. Em seu artigo 10 já aparece o conceito de "tortura", como "qualquer ato pelo qual dores ou sofrimentos agudos, físicos ou mentais, são infligidos intencionalmente a uma pessoa a fim de obter, dela ou de terceira pessoa, informações ou confissões; de castigá-la por ato que ela ou terceira pessoa tenha cometido, ou seja, suspeita de ter cometido". Fica 
evidente que, quando no Brasil ainda se praticam atos assemelhados (como espancamentos e mortes de suspeitos de crimes nas ruas, e torturas para obtenção de confissão por parte do próprio Estado), existe uma falta de consciência jurídica e, até mesmo, diplomática.

Não se pode dizer que o Estado trabalha para destruir essa visão primária dos direitos humanos, quando é ele mesmo um dos responsáveis por reiterar por meio de suas ações que a pessoa delinquente é uma figura demoníaca, vil, não humana e impossível de ser recuperada.

A comunidade deve enxergar os direitos humanos como aliados contra qualquer forma de opressão. Matar bandidos, como muitos pensam ser viável, é simplesmente um crime. Não há pena de morte no Brasil e, mesmo que houvesse, deveria ser decretada após o justo processo legal. Se o policial extermina um pretenso bandido, cuida-se de homicídio. $O$ apoio eventualmente recebido de parcela da comunidade é um desabafo coletivo de desgosto em face dos elevados índices de criminalidade. Pode ser compreensível, mas não justificável. Um bandido morto não é um bandido a menos, mas um crime a mais, elevando os índices de cometimento de delitos naquela localidade (NUCCI, 2016, p. 62).

Nesse contexto, a barbárie (própria do sistema capitalista e de sua lógica destrutiva) vai se expressar nos níveis mais absurdos de violência e de destruição dos direitos (historicamente conquistados), diga-se, nos modos de violação de direitos humanos ocasionados, sobretudo, por discriminações e fundamentalismos que implicam numa visão "reacionária" desses direitos.

Os efeitos de uma concepção reacionária de sociedade no campo dos direitos humanos são enormes. Suas ideias são, talvez, as que encontram maior enraizamento no nível do senso comum. É só pensarmos em quantas vezes ouvimos a frase 'direito humano é defesa de bandido'. Daí para a legitimação de tratamentos desumanos e cruéis contra milhares de pessoas, bem como brutalidades e mesmo assassinatos - tidos como heroicos pelos que defendem tal visão -, à defesa de políticas higienistas para as grandes cidades, que escondam o empobrecimento gerado pela desigualdade social e de renda, à violência contra os diferentes, é um simples passo. Resgata-se a ideia de que direitos devem existir apenas para 'pessoas de bem' - e excluem-se deste conceito inúmeros contingentes de trabalhadores pobres, desempregados (que não produziram por preguiça, não por condições concretas de vida), criminalizados e/ou privados de liberdade (RUIZ, 2014, p. 205).

Essas segregações atingem múltiplas camadas sociais, especialmente, as mais fracas, consideradas minoritárias. Se observarmos a realidade apontada no Anuário de Segurança Pública (2016), que destaca a população preta e parda como maiores vítimas da violência intencional, percebemos que o documento cita apenas o fator "raça/cor" 
como alarmante; no entanto, sabemos que os assassinatos decorrentes de outros "ódios institucionais", como os decursivos de homofobia e o feminicídio, que não foram problematizados no Anuário, embora tenhamos conhecimento de que sejam corriqueiros diante da realidade instaurada.

O Grupo Gay da Bahia (GGB) apresentou à sociedade um número de 318 assassinatos de pessoas homossexuais no ano de 2015 , no Brasil (52\% gays, $37 \%$ travestis, $16 \%$ lésbicas, $10 \%$ bissexuais), por exemplo. O delito de feminicídio, tipificado pela Lei no 13.104/2015, vem a responder aos exaustivos casos de assassinatos de mulheres no Brasil (ocasionados, puramente, por questões relativas ao gênero - das quais trataremos mais adiante, em específico).

Ligado à barbárie, o conservadorismo e sua reprodução ideológica são movidos historicamente por um conjunto de determinações que são estruturais e conjunturais. Por sua vez, fatores político-culturais e socioeconômicos, também compõem a teia desse processo. O modo de ser reproduzido pelo conservadorismo, fundado em valores de tradição e costumes, é mantido pelas elites, com preconceito de classe, de gênero, de raça, entre outros. É importante assinalar, ainda, que tudo isso é difundido e naturalizado, ou seja, são dissimuladas as contradições sociais e suas consequências naturalizadas.

Em momentos de crise social, o irracionalismo (que propaga o pessimismo, o individualismo e o anti-humanismo) e o conservadorismo encontram plenas condições para se desenvolverem e contribuem para a apologia da ordem capitalista (BARROCO, 2013).

Remetendo rapidamente à história, seria, então, com a consolidação do neoliberalismo em meados de 1990, marcado pelo período histórico de crise estrutural do capital, que seria revelado o caráter destruidor da natureza e da vida humana (MÉSZÁROS, 2009). Para Barroco (2015, p. 626) “Ao materializar-se na exploração, na dominação, na desigualdade, na violência objetiva e subjetiva, a acumulação capitalista e o neoliberalismo criaram as bases concretas para a reprodução social da barbárie manifesta em ideias, valores e comportamentos".

Nesta mesma década, ao menos, no caso brasileiro, a sociabilidade marcada estava pela cultura não só da violência, mas também do medo social. Tais fatos, presentes ainda hoje sob as "de sempre e as novas roupagens", fazem da temática dos direitos humanos uma complexa discussão, de grande diversidade e diversos interesses.

\subsection{As chagas do crime de estupro no Brasil}

A reflexão sobre os grilhões que prendem a mulher em sociedades machistas e patriarcais

Revista Publicum

Rio de Janeiro, v. 3, n. 1, 2017, p. 134-156.

http://www.e-publicacoes.uerj.br/index.php/publicum

DOI: $10.12957 /$ publicum.2017.26390 
vem sendo inserida incansavelmente na agenda global contemporânea. Tem sido mais do que necessária a luta contra uma cultura historicamente misógina que se estende à contemporaneidade e que ainda atribui à mulher o lugar da culpa, do objeto da opressão e da submissão em diversos níveis sociais, explícita ou implicitamente.

Reproduzido por várias instituições sociais, como a escola, a igreja e a família, o discurso da inferioridade, da objetificação e da espetacularização da mulher acaba por ser aceito como verdadeiro, impedindo a participação ativa das mulheres em diversos setores sociais e, pois, atentando contra a democratização da sociedade.

Nesse sentido, mais do que discutir o papel da mulher nas instituições sociais, a atual preocupação das nações comprometidas em erradicar e punir as diversas violências contra esse grupo é provocar reflexão sobre as questões de gênero, de identidade e de poder.

No seio social, a mulher carrega diversos estigmas, espécies de fundamentos solidificados historicamente. A sistemática dos direitos humanos vem trazer o debate em torno das questões que envolvem esses típicos "papéis de mulher", que não servem às vontades individuais; servem muito mais como um sistema que privilegia o direito ao controle do corpo feminino, disseminando uma cultura de sua apropriação.

Resultado dessa cultura predominantemente machista são os lamentáveis casos de estupros no Brasil. De acordo com o referido Anuário de Segurança Pública (2016), foram 125 vítimas diárias de estupro no país. O número de 45.460 pessoas estupradas (89\% do gênero feminino, isto é, a grande maioria) durante o ano de 2015 faz crucial uma pausa para indagações. Some-se a eles o número de tentativas de estupro no mesmo ano: 6.988.

De acordo com a Convenção Interamericana para Prevenir, Punir e Erradicar a Violência contra a Mulher, expedida em Belém do Pará, em 1994 (promulgada pelo Decreto $n$. ㅇ 1.973, de 10 de agosto de 1996): “entender-se-á por violência contra a mulher qualquer ato ou conduta baseada no gênero, que cause morte, dano ou sofrimento físico, sexual ou psicológico à mulher, tanto na esfera pública como na esfera privada".

Ao ratificar a Convenção, o Brasil assumia (há 20 anos) o compromisso de combater quaisquer manifestações dessas violências, não só por meio do direito penal, mas também, instrumentalizando políticas públicas, em conjunto com a educação, com a assistência social, com a cultura e todos os meios dos quais se servem os Estados para a efetivação de direitos.

A cultura de apropriação social do corpo feminino, detectada nos fortes números e relatos de estupros direcionados a esse gênero abre espaço para um exercício de questionamento sobre as pequenas ditaduras frias que vão se impondo sobre a 
humanidade e sobre as quais, não fossem os intensos debates promovidos por aqueles que creem nos direitos humanos, jamais refletiríamos.

Se é verdade que "a razão exprime um movimento contínuo, já que pensar não é repetir as falas dos outros, mas repensar tudo de novo" (KROHLING, 2009, p. 37), os dados recentes do Anuário de Segurança Pública direcionados ao estupro, irremediavelmente, obrigam um novo pensar sobre as questões de gênero e sobre o movimento feminista. $A$ renovação ganha importância mais intensa quando nos deparamos com uma forte onda conservadora, machista e patriarcal prestes a voltar à tona, colocando em risco os direitos e garantias conquistados pelas mulheres em séculos de luta.

Sabemos que "as questões de gênero estão imbricadas no modelo patriarcal de família e nas culturas de cada época histórica e de cada povo ou país" (KROHLING, 2009, p. 44); contudo, após um período de aparentes conquistas (tanto jurídicas, quanto sociais), o que tem se percebido é um forte movimento de novos rumores instigantes de ódio, de caos e de descaso com os direitos humanos de grupos minoritários, inclusive das mulheres.

Chega a impressionar a infinidade de regras supostamente morais que tolhem a mulher em sociedades fundadas no patriarcalismo. Ainda em 2016, a título de ilustração dessa realidade, o Fórum Brasileiro de Segurança Pública (em parceria com o Datafolha) divulgou que $30 \%$ dos homens e mulheres do Brasil concordam que a mulher que usa roupas consideradas "provocantes" não pode reclamar caso venha a ser estuprada.

O estupro, portanto, seria o paroxismo do domínio fálico. E mais ainda
legitimado e tolerado quando se entende que houve uma provocação da
vítima. Uma provocação não com o olhar, como ocorre nas imagens
fotográficas e nas artes plásticas, mas através de roupas curtas, andar e
movimentos de dança sensuais, como exemplos. Esses comportamentos
corporais dentro da cultura do domínio fálico instituído pelo patriarcado,
estariam, em realidade 'demandando' por serem subalternizados e
sucumbidos. Se a mulher foi estuprada e apresentou o seu corpo nessas
condições, em verdade, ela 'pediu' para isso. Não há o que se falar em culpa
daquele que a estuprou, ela sim, foi a culpada. A culpa é dela e a punição por
essa culpa é o próprio estupro. A culpa imediata é a culpa pela 'provocação',
a vítima provocou o seu algoz, esse ser inocente que foi engendrado em sua
teia irresistível de sedução. Mas, a culpa mediata, senão a originária, a de
fundo, é a culpa por estar apropriada de seu próprio corpo, de seus desejos e
de suas vontades. A culpa por refugir aos padrões de controle socialmente
impostos. Aos padrões de comportamento aos quais devem estar
enquadradas as mulheres nas sociedades patriarcais: os padrões do recato,
da submissão, do despoder (CAMPOS, 2016, p. 9).

O contexto é de determinação de um "papel de mulher" na sociedade que não leva em conta uma existência individual feminina, que não aceita as mulheres como donas de 
um corpo, de uma vida, de projetos e sonhos, muitas vezes, gradeados por forças opressoras que lhe são alheias.

Os reflexos do pensamento comum nos infinitos casos de violências sexuais divulgados pela mídia e denunciados diariamente ao Judiciário apontam para o modelo de mulher idealizado pelo imaginário social: petrificada, calada, obediente, passiva. $\mathrm{O}$ que nos mostra como Lipovetsky (2000, p. 15) tem razão quando diz que "[...] a moral sexual manifesta-se segundo um duplo padrão social: indulgência com as extravagâncias masculinas, severidade com a liberdade das mulheres".

Se vivemos em uma conjuntura na qual uma mulher não é livre para uma simples opção de vestuário - uma vez que isso já implica diretamente na culpabilização das violências por ela mesma sofridas (lembremos o ideário de blame the victim, termo cunhado pelo psicólogo William Ryan, em 1971) - como poderemos falar em garantir o amplo rol de direitos humanos dos quais é, também, a mulher destinatária?

A naturalização do crime de estupro por meio da atribuição da culpa à vítima é o simples e imediato resultado dos pressupostos impetrados à mulher pela sociedade essencialmente patriarcal. Os perfis de mulher como um sujeito pertencente ao amor único, submissa, recatada, dona do lar, amável, sempre fiel, constroem identidades supostamente reais que, no entanto, são apenas culturalmente impostas e obedecidas cegamente como imutáveis regras de conduta.

À mulher, quase sempre, são atribuídos o lugar da histeria, da irracionalidade, do excessivo passional, da falta de um domínio próprio de si. Brandão e Branco (2004, p. 133) bem sintetizam esse pensamento: “[...] a mulher, em nossa cultura, caracteriza-se sobretudo como um ser de falta [...]: é ela a que não possui. Destituída de voz, de poder, de intelecto, de alma, de pênis, resta-lhe a falta, a lacuna, esse lugar do vazio em que o feminino se instaura".

Quando olhamos para os nossos dados flagrantemente machistas, percebemos que o que se enxerga e se deseja ainda é uma mulher que se permita o domínio pelo outro. Sobretudo, se pensarmos na cultura Ocidental pós-Eva, em que a mulher ficou marcada por ser a raiz do "mal", a sedutora de Adão para o "pecado original". Crava-se, com essas lendárias, atribuições ao feminino, o espectro de um gênero para sempre culpado de si mesmo, vilão de sua própria história por toda a eternidade.

A esse respeito: 
[...] uma imagem da 'mulher' está em questão - uma imagem cuja predicação mínima como algo indeterminado já está disponível para a tradição falocêntrica. [...] a construção ideológica de gênero mantém a dominação masculina. Se, no contexto da produção colonial, o sujeito subalterno não tem história e não pode falar, o sujeito subalterno feminino está ainda mais profundamente na obscuridade (SPIVAK, 2010, pp. 66-67).

Esses estereótipos fincados no seio social reafirmam o ocultamento da mulher enquanto sujeito de direitos e precisam ser revisados, ou melhor, abolidos. É necessário um novo pacto social que compreenda que o alcance da igualdade entre homens e mulheres vai muito além de legislar a esse respeito. Em meados do século XX, unidas as preocupações com os direitos humanos e as teorias feministas, foi possível verificar a emergência de conversas e oscilações sociais.

As evidentes chagas de uma sociedade machista expõem os diversos interesses que estão em colisão no jogo de poder social, pautado no interesse pela desigualdade econômica, pela exploração do mais fraco, pela manutenção da figura mítica da "mulher tradicional", virgem e imaculada, subserviente e, sobretudo, disponível.

As pautas trazidas pelo movimento organizado de direitos humanos, bem como pelo movimento feminista, pensam em um processo de quebra de estereótipos e violências "[...] alicerçado na crença de que, consciente e coletivamente, as mulheres podem mudar a posição de inferioridade que ocupam no meio social" (ZOLIN, 2009, p. 220).

Essa consciência coletiva pode (deve, precisa) encontrar amparo no ordenamento jurídico. Por se tratar de tema de interesse universal, inclusive, não somente no ordenamento jurídico pátrio, como também nas esferas internacionais.

No caso do Brasil, os dados trazidos pelo Anuário (2016) são chocantes pela brutalidade, mas não pela novidade. Diversos setores das ciências vêm incluindo o crime de estupro como conteúdo de destaque na agenda dos direitos humanos. Além disso, incansáveis são as tentativas de movimentos sociais organizados de institucionalizar uma consciência coletiva a respeito dos fatores sociais que reafirmam uma cultura do estupro, bem como dos inúmeros direitos que ela faz retrocederem.

O crime de estupro (e seu "amém" velado) nega às mulheres direitos humanos fundamentais. Retira o acesso àquilo que é medular na existência humana: sua dignidade.

Mais amplamente, os números elevados do crime registrados no Brasil fazem com que se indague sobre a responsabilidade assumida pelo país no plano internacional. Afinal, o Capítulo III da já citada Convenção de Belém do Pará é destinado tão-somente a elencar os deveres dos Estados signatários para com a prevenção, a punição e a 
erradicação de qualquer tipo de violência contra a mulher. É um rol extenso de obrigações assumidas, entre medidas legislativas, judiciárias, administrativas e, sobretudo na prevenção: educacionais.

Destaquemos a alínea " $b$ ", do artigo 8 da Convenção:

Os Estados Partes convêm em adotar, progressivamente, medidas específicas, inclusive programas destinados a:

$[\ldots]$

modificar os padrões sociais e culturais de conduta de homens e mulheres, inclusive a formulação de programas formais e não formais adequados a todos os níveis do processo educacional, a fim de combater preconceitos e costumes e todas as outras práticas baseadas na premissa da inferioridade ou superioridade de qualquer dos gêneros ou nos papéis estereotipados para o homem e a mulher, que legitimem ou exacerbem a violência contra a mulher.

Note-se que, mais do que legislar e punir, o pacto internacional passa por um forte processo de conscientização. O problema vai além da judicialização. Os direitos humanos, em sua essência, prezam pelo estabelecimento de uma sociedade livre, plural e, sobretudo, consciente de sua diversidade e do valor de cada vida que habita o planeta. Longe de uma utopia ou de uma espécie de esperança pífia, as consequentes gerações (ou dimensões) dos direitos humanos convergem para a disseminação de um sentimento comum de alteridade. O Direito, enquanto ramo autônomo, é apenas um dos atores desse processo, mas - de maneira alguma - consegue somente pela legalidade atingir o alvo primeiro da consagração da dignidade humana enquanto supraprincípio.

É preciso agregar os mais diversos segmentos sociais para, como diz o texto da Convenção, excluir a "premissa da inferioridade ou superioridade de qualquer dos gêneros ou nos papéis estereotipados para o homem e a mulher". Já não se discute mais se esses estereótipos são inofensivos; já não é mais preciso verificar se há desigualdade de gêneros e se ela incita a violência contra a mulher. Esses pontos já foram discutidos, comprovados e publicamente disseminados como apenas alguns dos nossos maiores desafios.

Esse processo de soma, no entanto, não consegue se consolidar se o Estado não assume a postura de disseminar nos espaços de sua competência uma educação e uma cultura sustentadas pelos direitos humanos. Em vez disso, é o Estado o próprio responsável por inúmeras violações de direitos humanos, inclusive, das mulheres.

Isso porque, ao ser acionado por uma vítima de estupro, por exemplo, os braços estatais (exatamente devido à cultura misógina e machista, já apontada) agem com irresponsabilidade no trato das denunciantes. No caso do Brasil, em muitas situações, o 
ente estatal - em tese, o primeiro com o dever de proteger e acolher uma vítima de estupro - constrange e culpa a mulher, que acaba sofrendo para além da violência sexual.

A qualidade do atendimento é um fator decisivo para que se estimulem as denúncias de estupro (que são muito menores do que os reais casos desse crime). No entanto, são comuns os relatos de vítimas que se sentiram inibidas e subjugadas diante da justiça, no processo de denúncia e investigação do crime. Recorrentes são as acusações, as recriminações e os questionamentos, quase sempre direcionados à máxima: "mas... e o que você fez?".

A própria posição do Estado frente a essas questões é reflexo de um pensamento comum que ainda se baseia em ideais de servidão, de miséria e de uma dogmática coletiva desumana com relação à mulher.

Não é preciso (mas é sempre pertinente) recordar como esse comportamento viola diretamente toda a dinâmica do Direito Internacional dos Direitos Humanos e compromete desmedidamente o sistema ideal de limitação dos abusos do Estado frente à dignidade da pessoa humana. Sem contar que prejudica o desempenho do Brasil na execução de suas políticas de cumprimento ao pactuado em tratados internacionais de direitos humanos.

Todo esse conjunto de episódios nos serve como demonstração de que, de fato, ao se pensar no corpo e na sexualidade feminina, no Brasil, observa-se como as expectativas a eles relacionadas baseiam-se nos ecos do patriarcalismo. A cultura machista infiltrou de alguma maneira a ideia de que a mulher foi feita para pertencer e - a qualquer mínimo sinal de pertencimento do próprio corpo e do domínio pleno de sua sexualidade - existe forte retaliação por diversas forças sociais.

No âmbito dessas discussões, a mídia, por exemplo, é - também - reflexo da contramão da sociedade frente aos direitos humanos. Um estudo recentemente publicado, feito na cidade de Bauru (SP) preocupou-se em debater "a mídia do estupro". A autora sustenta sua pesquisa afirmando que: “A análise da produção midiática é, também uma análise social, tendo em vista que a mídia e a sociedade caminham lado a lado em sua evolução, num processo dinâmico que gera modificações umas nas outras" (CAIRES, 2016, p. 2).

Dentre outros dados interessantes, Caires - que estudou notícias com o tema "estupro contra mulheres" veiculadas no Jornal da Cidade (Bauru/SP), durante o mês de maio de 2015 - traz a público um ponto preciso para demonstrar a romantização do crime de estupro e a falta de seriedade e de reconhecimento do ato enquanto um dos mais repugnantes crimes contra a mulher. A questão levantada pela pesquisadora se refere à 
terminologia utilizada pela mídia estudada. Segundo dados da pesquisa: "a palavra estupro é utilizada 18 vezes nas 08 matérias. Ele também recebe o tratamento de crime (8 vezes), ataque (1), ataque sexual (2), abuso sexual (2) e relação sexual (4)".

Note-se que o termo "relação sexual" é o segundo mais citado depois de "crime" propriamente. O número revela como há um molde de mulher, entre cobranças e submissões, presa à subalternidade fastidiosa de uma cultura misógina. A pesquisadora enfatiza que: “A utilização da palavra relação sexual é problemática, pois, apesar de biologicamente ter acontecido a penetração, o fato não se constitui uma relação sexual. Estupro não é sexo" (CAIRES, 2016, pp. 8-9, grifo nosso). A falta de privacidade a qual a mídia expõe a mulher vítima de estupro também é decisiva.

Ao relatar um crime de estupro, as notícias analisadas enfatizam detalhadamente como é que o crime aconteceu. [...] Na maioria das matérias, apesar de não ser dito o nome da vítima, são relatadas muitas informações intimas, que uma mulher estuprada é obrigada a contar no boletim de ocorrência, mas não se sentiria à vontade para contar sequer para pessoas próximas. Se trata de um trauma, e não é parte da ética do jornalismo divulgar informações tão pessoais. Em lugar disso, seria uma questão de serviço público saber como o Estado e o sistema de Educação agem ou não para acabar com a cultura do estupro, da objetificação e posse masculina do corpo da mulher (CAIRES, 2016, pp. 9-10).

A autora destaca, ainda, outro dado curioso: o uso demasiado das expressões "alega que", "supostamente", "diz ter sido", "teria sido" - isto é, expressões que colocam dúvida a respeito da veracidade dos fatos relatados pela vítima, em uma presumida falsidade no depoimento ou na descrição dos fatos. Desmistificar essa cultura de presunção de culpa e falsidade no crime do estupro, colocando a mulher como sujeito ativo das próprias violações, é improrrogável, pois:

Não se trata apenas de uma posição militante feminista ou de uma urgência da mulher para se reabilitar a si própria. Trata-se em último termo de avançar para uma história que seja capaz de perceber a complexidade dos processos sociais desde uma ótica que tenha em conta a diversidade de sujeitos que participem deles. É evidente que o esquecimento, abandono, dissimulação, ou como queiramos dizer, da mulher como sujeito ativo em tão grande parte da historiografia não contribuiu de nenhuma maneira a proporcionar uma escrita histórica satisfatória, senão que ao contrário contribuiu a assentar a história como discurso ideológico das classes dominantes. (RAGO, 2012, p. 15)

As ideias advindas do conservadorismo, nesse sentido, estão inculcadas na população de forma aterradora. No dia 25 de outubro de 2016, a ONU divulgou uma pesquisa realizada pela ONU Mulheres (em parceria com o portal Papo de Homem). Os 
dados apontam que, para $81 \%$ dos homens entrevistados e para $95 \%$ das mulheres entrevistadas, o machismo é forte e permanece vivo em solo brasileiro.

A pesquisa, inclusive, indica certo desconforto do próprio público masculino, no que tange a ter que sustentar uma ideia de virilidade, dureza e frieza $(45,5 \%$ gostariam de se expressar de modo menos duro ou agressivo, mas não sabem como).

Todas essas questões desembocam na contumaz opressão sofrida pelo gênero feminino. Estado, mídia, família, religião, todas as forças atuantes delegam à mulher o lugar dessa "culpa perpétua". Como já dito anteriormente, a pretensão dos direitos humanos é afastar - instrumentalizando todos os meios cabíveis - essas convicções imbricadas no decorrer da história da humanidade. A educação, os meios de comunicação, o Estado e todo o sistema Legislativo e Judiciário deveriam ser parceiros da destituição desse pensamento.

As legislações nacionais devem cuidar para que os direitos acordados na Convenção sobre a Eliminação de Todas as Formas de Discriminação contra as Mulheres sejam inseridos em todos os âmbitos, seja social, político ou de trabalho. Este é o caminho inicial para que se destruam os estereótipos negativos. Com a lei será possível dar início ao processo de eliminação da violência contra as mulheres: pobreza, falta de educação, precariedade de atendimento de saúde, uso da mulher em conflitos armados e alienação da mulher dos cargos de poder e dos meios de comunicação. (CASTILHO, 2010, p. 213)

Fica claro com o que já demonstramos que os esforços em termos legais têm sido feitos. Embora o Direito não consiga agir sozinho na desconstrução desses dogmas (e reafirmamos que não há protagonismo de um ator social em específico nesse transcurso), não se pode também imaginar que o abandono da legalidade vai surtir algum efeito positivo nas ações de prevenção e combate ao estupro no país.

Contudo, essa concepção de lei como instrumento de eliminação da violência contra as mulheres trazida por Castilho (2010) só pode tomar rumos eficazes com o apoio das mais variadas esferas sociais, inevitavelmente.

\section{Considerações Finais}

O quadro exposto neste artigo é a pintura da segregação e da dificuldade humana no exercício da alteridade. As discussões trazidas apontam para um país em meio a uma verdadeira guerra não declarada, em um contexto de violência urbana incontrolável e de 
conservadorismo escancarado: peças de um quebra-cabeça, no mínimo, incabíveis para as "promessas da modernidade".

Ao passo que nos deparamos com uma necessidade imperiosa de cooperação e amparo e com uma gramática de direitos humanos cada vez mais determinada em buscar caminhos para a eficiência, os fatos convidam ao empreendimento de ações que coadunem com os ideais humanitários tão largamente estudados na academia, na esfera internacional e tão comentados enquanto preceitos civilizatórios.

Em última análise, o que concluímos na redação desta pesquisa é que existem múltiplas barreias para uma ideal implementação dos direitos humanos no Brasil. Obstáculos que tocam a esfera educacional, política, jurídica e, sobretudo, a cultural.

Acreditamos que somente um efetivo movimento de conscientização que atinja todas as camadas sociais - indistintamente - vá servir como uma construção firme da dogmática dos direitos humanos no seio social. Não se trata, a nosso ver, de uma limitação técnica - ao menos, não mais - uma vez que temos instrumentos jurídico-legais, conforme demonstramos, que poderiam servir de profícuos mecanismos, caso aliados a políticas melhor intencionadas e a um movimento de debates e conversas públicas acessíveis à população como um todo.

\section{Referências}

BARROCO, Maria Lúcia S. Lukács e a crítica do irracionalismo; elementos para uma reflexão sobre a barbárie contemporânea. In: DEL ROIO (Org.). Gyorgy Lukács e a emancipação humana. São Paulo: Boitempo; Marília: Editora Oficina Universitária, 2013.

. Não passarão! Ofensiva neoconservadora e Serviço Social. Serv. Soc. Soc., São Paulo, n. 124, p. 623-636, out./dez. 2015.

. O Significado sócio-histórico dos Direitos Humanos e o Serviço Social. Palestra apresentada na mesa Conflitos Globais e a violação dos Direitos Humanos: a ação do Serviço Social em 18/08/2008 - Conferência Mundial de Serviço Social da Federação Internacional de Trabalho - Salvador (Bahia). Disponível em: <http://www.cfess.org.br/pdf/maria_lucia_barroco.pdf.> Acesso: 10 nov de 2016.

BARROSO, Luís Roberto. Curso de direito constitucional contemporâneo: os conceitos fundamentais e a construção do novo modelo. 5. ed. São Paulo: Saraiva, 2015.

BRANDÃO, Ruth Silviano; BRANCO, Lucia Castello. A mulher escrita. Rio de Janeiro: Camparina Editora, 2004.

BRASIL. Constituição Federal de 1988. Disponível em: <http://www.planalto.gov.br/ccivil_03/constituicao/constituicao.htm>. Acesso em: 4 out. 2016. 
. Fórum Brasileiro de Segurança Pública. 10 Anuário Brasileiro de Segurança Pública. $2016 . \quad$ Disponível em: <http://www.forumseguranca.org.br/storage/download//anuario-2016-03nov-final.pdf>. Acesso em: 6 nov. 2016.

\begin{tabular}{lcccr} 
Lei & no & 13.104/2015. & Disponível & em: \\
\hline <http://www.planalto.gov.br/ccivil_03/_Ato2015-2018/2015/lei/L13104.htm>. & Acesso
\end{tabular} em: 05 out. 2016.

Decreto n. 1.973, de 1ำ de agosto de 1996. Disponível em: <http://www.planalto.gov.br/ccivil_03/decreto/1996/d1973.htm>. Acesso em: 25 out. 2016.

BRITO, Felipe; VILLAR, André; BLANK, Javier. "Será guerra?". In: BRITO, Felipe; OLIVEIRA, Pedro Rocha (Org.). Até o último homem: visões cariocas da administração armada da vida social. São Paulo: Boitempo, 2013.

CAIRES, Mariana de Sousa. A Mídia do Estupro: análise de notícias sobre violência sexual durante o mês de maio de 2015. Anagrama, v. 10, n. 1, 2016.

CAMPOS, Andrea Almeida. A cultura do estupro como método perverso de controle nas sociedades patriarcais. Revista Espaço Acadêmico, v. 16, n. 183, p. 01-13, 2016.

CASTILHO, Ricardo. Direitos Humanos: processo histórico - evolução no mundo, direitos fundamentais: constitucionalismo contemporâneo. São Paulo: Saraiva, 2010.

CORREIA, Marcus Orione Gonçalves. Interpretação dos direitos fundamentais sociais, solidariedade e consciência de classe. In: CANOTILHO, J.J. Gomes. Direitos fundamentais sociais. São Paulo: Saraiva, 2010.

GONÇALVES, Tamara Amoroso. Direitos humanos das mulheres e a Comissão Interamericana de Direitos Humanos. Trad. de notas e citações Luciana Yonekawa. São Paulo: Saraiva, 2013.

GGB. Grupo Gay da Bahia. Assassinato de LGBT no Brasil: Relatório 2015. Disponível em: $<$ https://grupogaydabahia.com.br/2016/01/28/assassinato-de-Igbt-no-brasil-relatorio2015/>. Acesso em: 8 nov. 2016.

KROHLING, Aloísio. Direitos Humanos Fundamentais: diálogo intercultural e democracia. São Paulo: Paulus, 2009.

LIPOVETSKY, Gilles. A terceira mulher: permanência e revolução do feminino. Tradução de Maria Lucia Machado. São Paulo: Companhia das Letras, 2000.

MAZZUOLI, Valerio de Oliveira. Curso de direitos humanos. Rio de Janeiro: Forense; São Paulo: MÉTODO, 2014.

MÉSZÁROS, Istvan. A crise estrutural do capital. São Paulo: Boitempo, 2009. (Col. Mundo do Trabalho.) 
NUCCI, Guilherme de Souza. Direitos humanos versus segurança pública. Rio de Janeiro: Forense, 2016.

ONU MULHERES. Disponível em: <http://www.onumulheres.org.br/noticias/81-doshomens-consideram-o-brasil-um-pais-machista/>. Acesso em: 9 nov. 2016.

PIOVESAN, Flavia. A Constituição brasileira de 1988 e os tratados internacionais de proteção dos direitos humanos. Revista Jurídica da Faculdade de Direito/Faculdade Dom Bosco, v. 2, n. 1, p. 20-33, 2008.

Temas de direitos humanos. 9. ed. rev., ampl. e atual. São Paulo: Saraiva, 2016.

PIOVESAN, Flávia; GOMES, Luiz Flávio. O sistema interamericano de proteção dos direitos humanos e o direito brasileiro. São Paulo: Editora Revista dos Tribunais, 2000.

RAGO, Margareth. Gênero e história. Espanha CNT-Compostela, 2012.

RAMOS, André de Carvalho. Curso de direitos humanos. 3. ed. rev., atual. e ampl. São Paulo: Saraiva, 2016.

RUIZ, Jefferson Lee de Souza. Direitos humanos e concepções contemporâneas. São Paulo: Cortez, 2014.

SPIVAK, Gayatri Chakravorty. Pode o subalterno falar? Tradução de Sandra Regina Goulart Almeida, Marcos Pereira Feitosa, André Pereira Feitosa. Belo Horizonte: Editora UFMG, 2010.

ZOLIN, Lúcia Osana. Crítica Feminista. In: ZOLIN, Lúcia Osana; BONNICl, Thomas. (Orgs.). Teoria literária: abordagens históricas e tendências contemporâneas. 3. ed. rev. ampl. Maringá: Editora Eduem, 2009, p. 217-242.

Enviado em: 18/11/2016

Aprovado em: 25/06/2017 